\title{
Physiological responses of sweet potato (Ipomoea batatas L.) plants due to different copper concentrations
}

\section{Respostas fisiológicas de plantas de batata-doce (Ipomoea batatas L.) submetidas a diferentes concentrações de cobre}

\author{
Cristina Copstein Cuchiara ${ }^{1 *}$; Mara Cíntia Winhelmann²; Cristina Ferreira Larré1; \\ Juliana Aparecida Fernando ${ }^{3}$; Eugenia Jacira Bolacel Braga ${ }^{3}$; José Antonio Peters ${ }^{4}$
}

\begin{abstract}
At low concentrations, $\mathrm{Cu}$ is considered as an essential micronutrient for plants and as a constituent and activator of several enzymes. However, when in excess, $\mathrm{Cu}$ can negatively affect plant growth and metabolism. Therefore, the aim of this study was to evaluate physiological responses of sweet potato plants at different $\mathrm{Cu}$ concentrations by measuring morphological parameters, antioxidant metabolism, stomatal characteristics, and mineral profile. For this purpose, sweet potato plants were grown hydroponically in complete nutrient solution for six days. Then, the plants were transferred to solutions containing different $\mathrm{Cu}$ concentrations, 0.041 (control), 0.082, and $0.164 \mathrm{mM}$, and maintained for nine days. The main effect of increased $\mathrm{Cu}$ concentration was observed in the roots. The sweet potato plants grown in 0.082 $\mathrm{mM} \mathrm{Cu}$ solution showed increased activity of antioxidant enzymes and no changes in growth parameters. However, at a concentration of $0.164 \mathrm{mM}, \mathrm{Cu}$ was transported from the roots to the shoots. This concentration altered morpho-anatomical characteristics and activated the antioxidant system because of the stress generated by excess $\mathrm{Cu}$. On the basis of the results, it can be concluded that the sweet potato plants were able to tolerate $\mathrm{Cu}$ toxicity until $0.082 \mathrm{mM}$. Key words: Micronutrient, antioxidant metabolism, mineral content, copper sulfate, stress
\end{abstract}

\section{Resumo}

O cobre, em baixas concentrações, é considerado micronutriente essencial para as plantas por ser constituinte e ativador de diversas enzimas. Porém, quando em excesso, pode afetar negativamente o crescimento, o desenvolvimento e o metabolismo vegetal. Com base no exposto, o objetivo do trabalho foi avaliar as respostas fisiológicas de plantas de batata-doce quando submetidas a diferentes concentrações de cobre através dos parâmetros morfológicos, índice de clorofila, metabolismo antioxidante, perfil mineral e características estomáticas. Para tanto, as mesmas foram cultivadas em sistema hidropônico com solução nutritiva completa por seis dias. Após este período foram transferidas para soluções contendo diferentes concentrações de cobre: 0,041 (controle); 0,082 e 0,164 mM, onde permaneceram por nove dias. Nas raízes, o principal efeito do aumento da concentração de cobre foi

\footnotetext{
${ }^{1}$ Biólogas, Dras em Fisiologia Vegetal, Dept ${ }^{\circ}$ de Botânica, DB, Instituto de Biologia, IB, Universidade Federal de Pelotas, UFPel, Capão do Leão, RS, Brasil. E-mail: cccuchiara@hotmail.com; cristina_larre@yahoo.com.br

2 Discente do Curso de Graduação em Agronomia, Faculdade de Agronomia Eliseu Maciel, FAEM, UFPel, Capão do Leão, RS, Brasil. E-mail: marawinhelmann@yahoo.com.br

${ }^{3}$ Biólogas, Prof ${ }^{\text {as }}$ Dras , DB, IB, UFPel, Capão do Leão, RS, Brasil. E-mail: juli_fernando@yahoo.com.br; jacirabraga@hotmail.com

${ }^{4}$ Eng $^{\text {o }}$ Agr $^{\circ}$, Prof. Dr., DB, IB, UFPel, Capão do Leão, RS, Brasil. E-mail: japeters1@hotmail.com

* Author for correspondence
} 
o acúmulo do mesmo nesse órgão. As plantas de batata-doce cultivadas com 0,082 $\mathrm{mM}$ de cobre na solução, apresentaram aumento da atividade das enzimas antioxidantes sem nenhuma alteração na taxa de crescimento. No entanto, na concentração de $0,164 \mathrm{mM}$, o cobre foi transportado das raízes para a parte aérea. Essa concentração reduziu o crescimento, alterou características morfo-anatômicas e ativou o sistema antioxidante como forma de proteção ao estresse gerado pelo excesso de cobre. Com base nos resultados, pode-se concluir que as plantas de batata-doce foram capazes de tolerar a toxidez por $\mathrm{Cu}$ até a concentração de $0,082 \mathrm{mM}$.

Palavras-chave: Micronutriente, perfil mineral, sulfato de cobre, estresse

\section{Introduction}

Heavy metals occur naturally in the environment; however, their concentrations are often elevated as a result of various anthropogenic processes such as mining, smelting, application of pesticides and inorganic fertilizers, and atmospheric emissions (HARICHOVÁ et al., 2012). Environmental contamination by heavy metals has become a serious problem for plants, animals, aquatic life, and humans (HARICHOVÁ et al., 2012). Among the different toxic heavy metals in the environment, $\mathrm{Cu}$ is the most important and studied contaminant (CAMBROLLÉ et al., 2013).

At low concentrations, $\mathrm{Cu}$ is considered as an essential micronutrient for plants and as a constituent and activator of several enzymes (BURKHEAD et al., 2009). However, when in excess, $\mathrm{Cu}$ can negatively affect plant growth and metabolism (FIDALGO et al., 2013). Limits of $\mathrm{Cu}$ concentration in tissues vary among species and differentially affect metabolic requirements (BURKHEAD et al., 2009).

Excess $\mathrm{Cu}$ concentrations interfere directly with photosynthesis and can reduce electron transport and inhibit enzymes of the Calvin-Benson cycle or the rate of $\mathrm{CO}_{2}$ assimilation (BURZYNSKI; ZUREK, 2007; SILVA et al., 2010). In addition to the damage to the photosynthetic process, high concentrations of $\mathrm{Cu}$ have been related to changes in pigment content and structure of the chloroplast (SHI-SHENG, 2007).

Excess $\mathrm{Cu}$ concentrations have been related to oxidative stress generation (SHI SHENG, 2007) and connected to the production of reactive oxygen species (ROS) in Fenton-like redox reactions (FIDALGO et al., 2013). ROS are generated as natural products of photosynthetic and aerobic metabolisms in plants. At low concentrations, ROS can serve as signaling molecules in the redox signal transduction pathway in plants (SILVA et al., 2010). However, plants are better able to protect themselves against homeostatic disturbance and cellular damage by inducing antioxidant enzymes as a general response to the toxic effects of heavy metals (BOOJAR; GOODARZI, 2007).

Changes in stomatal characteristics may result in tolerance to different environmental conditions such as drought, flooding, and stress due to metals such as $\mathrm{Cu}$ (PANOU-FILOTHEOU et al., 2001; RIBEIRO et al., 2012), promoting changes mainly in the stomata. Stomata are sensitive and important for plant growth and development. They have a prominent role in regulating both transpiration flow to the atmosphere and $\mathrm{CO}_{2}$ flow into leaves (SILVA et al., 2005). Stomata may vary in shape, size, and quantity on the basis of abiotic factors that cause changes in photosynthetic conditions (ADAMSKI et al., 2012).

Plants that grow in environments with high $\mathrm{Cu}$ concentrations can develop defense mechanisms against toxicity (CAMBROLLÉ et al., 2013). The extent of such tolerance and the degree of adaptation are highly variable, and efficiency and capacity of detoxification mechanisms play an important role (BOOJAR; GOODARZI, 2007). In addition, a network of sequestration activities and immobilization functions regulate the uptake, 
distribution, and detoxification of excess metal ions in plants (JANAS et al., 2010).

Sweet potato [Ipomoea batatas (L.) Lam.] is a vegetable known for its ease of cultivation, hardiness, adaptation to different soil types and climate, high tolerance to drought, high biomass, and low production cost (LOW et al., 2007; ANDRADE JÚNIOR et al., 2012). In addition to these characteristics, sweet potato has been used as a model plant in studies of plant nutrition and metabolism because of the ease of propagation and fast growth (ADAMSKI et al., 2011, 2012; FOLONI et al., 2013).

The objective of this study was to evaluate the physiological responses of sweet potato plants to different $\mathrm{Cu}$ concentrations by measuring growth parameters, chlorophyll content, antioxidant metabolism, mineral profile, and stomatal characteristics.

\section{Materials and Methods}

Sweet potato (Ipomoea batatas L. 'ILS19') plants were obtained from apical branches that were approximately $8 \mathrm{~cm}$ in length and had four leaves per branch of plants rooted for five days in distilled water in a greenhouse. After rooting, the plants were placed in a continuous-flow rootfloating hydroponic system and were cultured using the Hoagland and Arnon (1938) complete nutrient solution for six days. The plants were then cultured in a nutrient solution for nine days at different $\mathrm{Cu}$ concentrations: $0.041,0.082$, and $0.164 \mathrm{mM}$ in the form of $\mathrm{CuSO}_{4} \cdot 5 \mathrm{H}_{2} \mathrm{O}$. Treatments were determined after preliminary experiments, which showed that cultivation in concentrations lower than those mentioned above did not cause changes in growth parameters, and the control concentration was set at $0.041 \mathrm{mM} \mathrm{Cu}$. Every three days, the solution was renewed, and the $\mathrm{pH}$ was adjusted to \pm 5.8 . At the end of the stress period, the plants were collected and evaluated for growth parameters, chlorophyll content, antioxidant metabolism, mineral profile, and stomatal characteristics.

The following growth parameters were evaluated: branch length, determined with a metric ruler $(\mathrm{cm})$; leaf number; fresh weight of shoot and root (mg); dry weight of shoot and root, measured with an analytical scale after drying the material in a forced ventilation oven at $70{ }^{\circ} \mathrm{C} \pm 2{ }^{\circ} \mathrm{C}$ until a constant weight was achieved (mg); and leaf area, measured using a leaf area meter (LI-3000, LI-COR Inc., Lincoln, NE, USA) $\left(\mathrm{cm}^{2} \cdot\right.$ plant $\left.^{-1}\right)$. Chlorophyll content was estimated using a portable chlorophyll meter (CL-01, Hansatech, King's Lynn, Norfolk, UK), and the results were expressed using the chlorophyll index (CASSOL et al., 2008).

Antioxidant enzyme activities in young leaves and roots were determined. Approximately $200 \mathrm{mg}$ of fresh leaf tissue from each sample was ground in liquid $\mathrm{N}_{2}$ with $20 \%$ polyvinylpolypyrrolidone and homogenized in $1.8 \mathrm{~mL}$ of an extraction medium (100 mM potassium phosphate buffer, $\mathrm{pH}$ 7.8; $0.1 \mathrm{mM}$ EDTA; and $20 \mathrm{mM}$ ascorbic acid). The homogenate was centrifuged at $13,000 \times g$ for 20 $\min \left(4^{\circ} \mathrm{C}\right)$, and the supernatant was collected to determine enzymatic activity and quantify proteins by using the Bradford method (BRADFORD, 1976).

Superoxide dismutase activity (SOD, EC 1.15.1.1) was determined on the basis of the ability of SOD to inhibit the photoreduction of nitroblue tetrazolium (NBT) (GIANNOPOLITIS; RIES, $1977)$ in a reaction medium $(100 \mathrm{mM}$ potassium phosphate, $\mathrm{pH} 7.8 ; 14 \mathrm{mM}$ methionine; $0.1 \mu \mathrm{M}$ EDTA; $75 \mu \mathrm{M}$ NBT; and $2 \mu \mathrm{M}$ riboflavin). One unit of SOD was considered as the amount of enzyme able to inhibit $50 \%$ NBT photoreduction under test conditions. The results were expressed in $\mathrm{U} \mathrm{mg}^{-1}$ protein.

Ascorbate peroxidase activity (APX, EC 1.11.1.11) was evaluated according to the method described by Nakano and Asada (1981), that is, by monitoring the oxidation rate of ascorbate (ASA) at $290 \mathrm{~nm}$. The incubation buffer was composed 


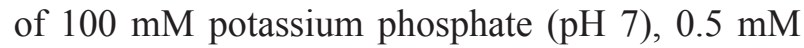
ascorbic acid, $0.1 \mathrm{mM} \mathrm{H}_{2} \mathrm{O}_{2}$ and enzyme extract. The decrease in absorbance was monitored over a period of $1.5 \mathrm{~min}$, and the results were expressed in $\mu \mathrm{mol} \mathrm{ASA} \mathrm{min}^{-1} \mathrm{mg}^{-1}$ protein.

Catalase activity (CAT, EC 1.11.1.6) was determined as described by Azevedo et al. (1998). The enzyme extract was added to a reaction medium (100 mM potassium phosphate buffer, $\mathrm{pH} \mathrm{7,} \mathrm{and}$ $12.5 \mathrm{mM} \mathrm{H}_{2} \mathrm{O}_{2}$ ), and the activity was indicated by decreased absorbance at $240 \mathrm{~nm}$ over a period of $1.5 \mathrm{~min}$. The results were expressed in $\mu \mathrm{mol} \mathrm{H}_{2} \mathrm{O}_{2}$ $\min ^{-1} \mathrm{mg}^{-1}$ protein.

The levels of macronutrients $(\mathrm{N}, \mathrm{Ca}$, and $\mathrm{Mg}$ ) and micronutrients $(\mathrm{Cu}$ and $\mathrm{Fe})$ were determined from the dry weights of leaves and roots, according to the methods reported by Tedesco et al. (1995). Nutrient levels were evaluated in leaves that had already been established before the $\mathrm{Cu}$ treatments (called "old leaves"), leaves that developed after the $\mathrm{Cu}$ treatments (called "young leaves"), and roots.

For stomatal evaluation, fully expanded young leaves from the second or third branch nodes were collected and fixed in Karnosky solution (RUZIN, 1999). Paradermal cuts were manually made in the middle third of the leaves and cleared in 5\% sodium hypochlorite solution. Then, each section was stained with $0.05 \%$ toluidine blue solution in $0.1 \mathrm{M}$ phosphate buffer (KRAUS; ARDUIN, 1997) and mounted on microscope slides in 50\% glycerin. The sections were observed and photographed using a Zeiss Axiostar Plus optical microscope (Carl Zeiss, Light Microscopy, Gottingen, Germany) and a Sony digital camera, (model EX MPEG Movie, 3.3 megapixels). The images were digitized at 20× magnification. According Adamski et al. (2012), stomatal index (SI, percentage of stomata in relation to total epidermal cells) of the abaxial (Ab) and adaxial (Ad) epidermis in two areas for five plants per treatment was observed. For polar diameter (SPD, length of guard cells) and equatorial diameter (SED, width of guard cells), five plants per treatment were evaluated and five stomata per plant were measured. To measure the dimensions of the stomata, Zeiss-Axio Vision 3.1 software was used. SI was calculated using the Cutter equation (CUTTER, 1986): SI $=[\mathrm{SN} /(\mathrm{ECN}+\mathrm{SN})] \times 100$, where SI = stomatal index; $\mathrm{SN}=$ stomatal number; and $\mathrm{ECN}=$ epidermal cell numbers.

The experiment was performed using a completely randomized design that consisted of three doses of $\mathrm{Cu}(0.041,0.082$, and $0.164 \mathrm{mM})$ and five replicates (five plants per replicate). The results were subjected to analysis of variance, and the means were compared using Tukey's test at 5\% significance with Winstat software (MACHADO; CONCEIÇÃO, 2003).

\section{Results and Discussion}

Although the sweet potato plants treated with different $\mathrm{Cu}$ concentrations survived the experiment, they showed some typical visible characteristics of $\mathrm{Cu}$-induced toxicity. According to Cambrollé et al. (2012), chlorosis and growth inhibition are described as common symptoms in most plants grown at high $\mathrm{Cu}$ concentrations. In this study, plants grown at 0.041 and $0.082 \mathrm{mM} \mathrm{Cu}$ concentrations showed no difference in growth parameters; however, exposure to $0.164 \mathrm{mM} \mathrm{Cu}$ concentration caused a drastic decrease in the analyzed variables $(p<0.05$; Figure $1)$. Branch length $(p=0.0002)$, leaf number $(p=$ $0.0005)$, and leaf area $(p=0.003)$ of plants cultivated at $0.164 \mathrm{mM} \mathrm{Cu}$ concentration were 29, 56, and $21 \%$, respectively, of the control values. Similarly, for fresh shoot weight $(p=0.002)$ and free root weight $(p=0.01)$ and dry shoot weight $(p=0.02)$ and dry root weight $(\mathrm{p}=0.005)$, plants cultivated using the highest $\mathrm{Cu}$ concentration showed 19, 46, 24 , and $40 \%$, respectively, of the values observed for the control plants. These results show that the strategy of plants under stress due to high metal concentrations is to use tolerance mechanisms, limiting other processes such as growth (POSMYK et al., 2009; LARRÉ et al., 2014). Furthermore, 
recent studies have shown a relationship between the biochemical phase of photosynthesis, which is highly sensitive to the effects of heavy metals, and the decrease in growth (SHI-SHENG, 2007).

Figure 1. Effect of copper $(\mathrm{Cu})$ in sweet potato plants (Ipomoea batatas L.) on the following growth parameters: (A) Shoot length (cm); (B) Leaf number; (C) Leaf area $\left(\mathrm{cm}^{2}\right.$ plant $\left.^{-1}\right)$; (D) Chlorophyll index; (E) Shoot fresh weight (mg); (F) Root fresh weight (mg); (G) Shoot dry weight (mg); (H) Root dry weight (mg). Means followed by the same letter do not differ according to Tukey's test $(\mathrm{p}>0.05)$.
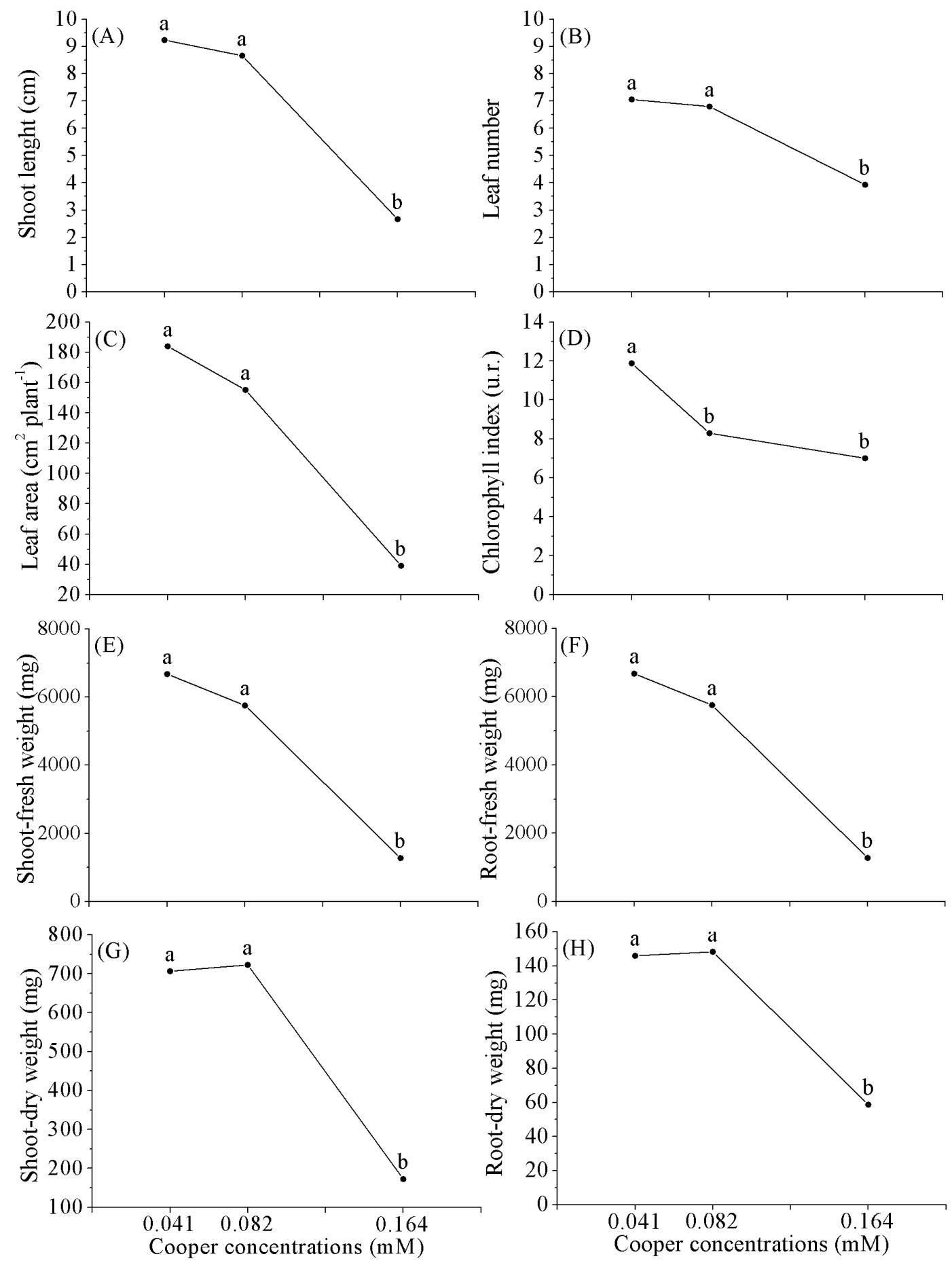
Leaf chlorosis was not visibly observed in the sweet potato plants; however, at the intracellular level, there was a decrease in the content of photosynthetic pigments; this effect may be associated with $\mathrm{Cu}$ toxicity (LIU et al., 2004; MOURATO et al., 2009). The highest $\mathrm{Cu}$ concentrations $(0.082$ and $0.164 \mathrm{mM})$ caused a significant decrease of $69 \%$ in chlorophyll content $(\mathrm{p}=0.0001$; Figure 1D). According to Xiong et al. (2006) and Adamski et al. (2011), chlorophyll biosynthesis is dependent on the supply of assimilated $\mathrm{N}$ and $\mathrm{Fe}$, and substitution of the central
$\mathrm{Mg}$ ion by $\mathrm{Cu}$ in the chlorophyll molecule causes damage to the chlorophyll-synthesizing system (CAMBROLLÉ et al., 2013). The mineral profile of the sweet potato plants (Figure 2) suggests that higher concentrations of $\mathrm{Cu}(0.082$ and $0.164 \mathrm{mM})$ (1) considerably reduced the foliar concentration of some macronutrients, such as $\mathrm{Mg}, \mathrm{Ca}$, and $\mathrm{N}$; (2) caused Fe immobilization in the roots and this micronutrient was probably not translocated to chlorophyll synthesis system in the leaves; and (3) led to the degradation of chlorophyll molecules (MATEOS-NARANJO et al., 2008).

Figure 2. Effect of copper $(\mathrm{Cu})$ in sweet potato plants (Ipomoea batatas L.) on the following nutrients: (A) Nitrogen content (N); (B) Calcium content (Ca); (C) Magnesium content (Mg); (D) Copper content (Cu); (E) Iron content (Fe).
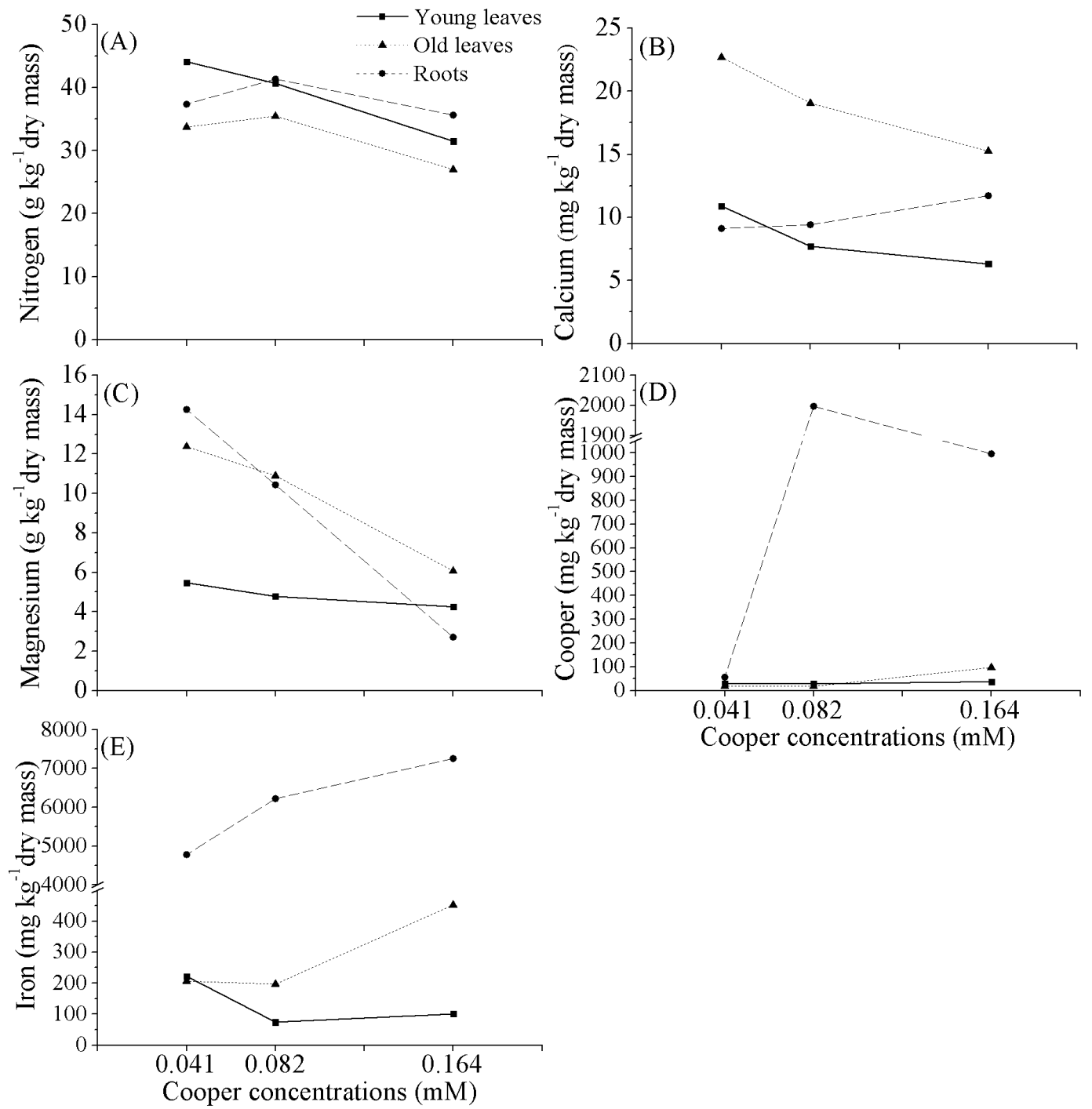
SI is a parameter that provides information on cell differentiation in the epidermal leaf surface (TICHÁ, 1982), and diameter of the stomata is directly related to the size of these structures; environmental conditions can influence these characteristics (RIBEIRO et al., 2012). Sweet potato leaves are characteristically amphistomatic and have paracytic stomata (GLÓRIA; GUERREIRO, 2006). In the adaxial epidermis,
$\mathrm{Cu}$ did not cause any stomatal changes $(\mathrm{p}<0.05$; Table 1). However, in the abaxial epidermis, SI was increased by $34 \%$ with an increase in $\mathrm{Cu}$ concentration $(\mathrm{p}=0.0003)$. The increase in $\mathrm{Cu}$ concentration caused a decrease in polar and equatorial diameters of abaxial epidermis stomata ( $p>0.05$ ), reducing the polar diameter by about $19 \%$ at higher $\mathrm{Cu}$ concentrations and the equatorial diameter by $9 \%(\mathrm{p}=0.01)$.

Table 1. Stomatal index and diameter (mean \pm SEM) of sweet potato leaves (Ipomoea batatas L.) cultivated at different copper $(\mathrm{Cu})$ concentrations.

\begin{tabular}{lccc}
\hline \multicolumn{4}{c}{ Cooper concentrations (mM) } \\
\hline \multicolumn{4}{c}{ ADAXIAL EPIDERMIS } \\
\hline Characteristics & 0.041 & 0.082 & 0.164 \\
\hline SIAd $^{n s}$ & $4.67 \pm 0.39 \mathrm{a}$ & $5.56 \pm 0.40 \mathrm{a}$ & $4.74 \pm 0.38 \mathrm{a}$ \\
SPDAd $^{\mathrm{ns}}$ & $19.74 \pm 0.27 \mathrm{a}$ & $18.59 \pm 0.38 \mathrm{a}$ & $18.31 \pm 0.46 \mathrm{a}$ \\
SEDAd $^{\mathrm{ns}}$ & $13.65 \pm 0.13 \mathrm{a}$ & $13.45 \pm 0.20 \mathrm{a}$ & $13.25 \pm 0.35 \mathrm{a}$ \\
\hline \multicolumn{4}{c}{ Cooper concentrations (mM) } \\
\hline \multicolumn{4}{c}{ ABAXIAL EPIDERMIS } \\
\hline Characteristics $^{*} 0.041$ & 0.082 & 0.164 \\
SIAb $^{* *}$ & $19.73 \pm 1.52 \mathrm{~b}$ & $29.32 \pm 0.71 \mathrm{a}$ & $2651 \pm 1.10 \mathrm{a}$ \\
SPDAb $^{* *}$ & $19.40 \pm 0.30 \mathrm{a}$ & $16.95 \pm 0.20 \mathrm{~b}$ & $16.30 \pm 0.42 \mathrm{~b}$ \\
SEDAb $^{* *}$ & $13.87 \pm 0.24 \mathrm{a}$ & $13.34 \pm 0.32 \mathrm{ab}$ & $12.67 \pm 0.39 \mathrm{~b}$ \\
\hline
\end{tabular}

SIAd = stomatal index in the adaxial epidermis; SPDAd = stomatal polar diameter in the adaxial epidermis; SEDAd = stomatal equatorial diameter in the adaxial epidermis; SIAb = stomatal index in the abaxial epidermis; SPDAb = stomatal polar diameter in the abaxial epidermis; SEDAb $=$ stomatal equatorial diameter in the abaxial epidermis; ${ }^{* *}$, significant at $5 \%$ significance level. ${ }^{\text {ns }}$ not significant.

High $\mathrm{Cu}$ concentrations resulted in a reduction in the size of stomata; conversely, the number of stomata increased. The opposite response was observed in leaves treated with $0.041 \mathrm{mM} \mathrm{Cu}$. Studies have shown that the number of stomata is inversely proportional to the size of the guard cells, reflecting better control of the transpiration rate (PANOU-FILOTHEOU et al., 2001). According to Ribeiro et al. (2012), this response may be associated with increased stomatal functionality because the stomata become more elliptical. This behavior is often observed at high light intensity and low water availability. Thus, these results also indicate the presence of heavy metals during stomatal initiation, development, and function (RIBEIRO et al., 2012).

Excess $\mathrm{Cu}$ concentrations can catalyze the generation of harmful reactive oxygen species (ROS) such as superoxide anion $\left(\mathrm{O}_{2}{ }^{*}\right)$, hydrogen peroxide $\left(\mathrm{H}_{2} \mathrm{O}_{2}\right)$, and hydroxyl radical $\left(\mathrm{OH}^{*}\right)$, and they can damage biological molecules (DNA, RNA, and proteins) and cellular membranes. Ability of these antioxidases, SOD, CAT, and APX, to remove ROS, depending on the relationship between these enzymes, is the key factor in determining the resistance of plant cells to environmental stresses (SHI-SHENG, 2007). SOD, which is considered as the first line of antioxidant defense (MITTLER, 2002), has the function of dismutating $\mathrm{O}_{2}{ }^{*}$ in $\mathrm{H}_{2} \mathrm{O}_{2}$ 
(MELONI et al., 2003). $\mathrm{H}_{2} \mathrm{O}_{2}$ is highly toxic and needs to be degraded by CAT and APX (MITTLER, 2002).

In the leaf tissues, activities of SOD and APX showed no significant difference between treatments $(p>0.05$; Figure $3 \mathrm{~A}$ and $3 \mathrm{~B})$. However, CAT enzyme activity at $0.164 \mathrm{mM} \mathrm{Cu}$ was 2.6 times higher than that at other $\mathrm{Cu}$ concentrations $\left(\mathrm{p}=0.005\right.$; Figure 3C). CAT can eliminate $\mathrm{H}_{2} \mathrm{O}_{2}$ from plants by degradation to water and $\mathrm{O}_{2}$, and it is mainly located in the peroxisomes. It is produced under oxidative stress conditions in the presence of heavy metals and metalloids (MITTLER, 2002; THOUNAOJAM et al., 2012). CAT activity can be related to the photorespiration cycle, which increases $\mathrm{H}_{2} \mathrm{O}_{2}$ content in peroxisomes, and this could justify an increase in the activity of this enzyme in the leaves. Photorespiration is considered as an alternative sink to help in consuming the reduction power (NADPH) generated by the electron transport chain in the chloroplast (WINGLER et al., 1999).

Figure 3. Effect of copper $(\mathrm{Cu})$ in sweet potato plants (Ipomoea batatas L.) on antioxidant metabolism: (A) Superoxide dismutase (SOD); (B) Ascorbate peroxidase (APX); (C) Catalase (CAT). Means followed by the same lowercase letters do not differ according to Tukey's test at $5 \%$ error probability. Means followed by the same uppercase letters do not differ according to Tukey's test at 5\% error probability.
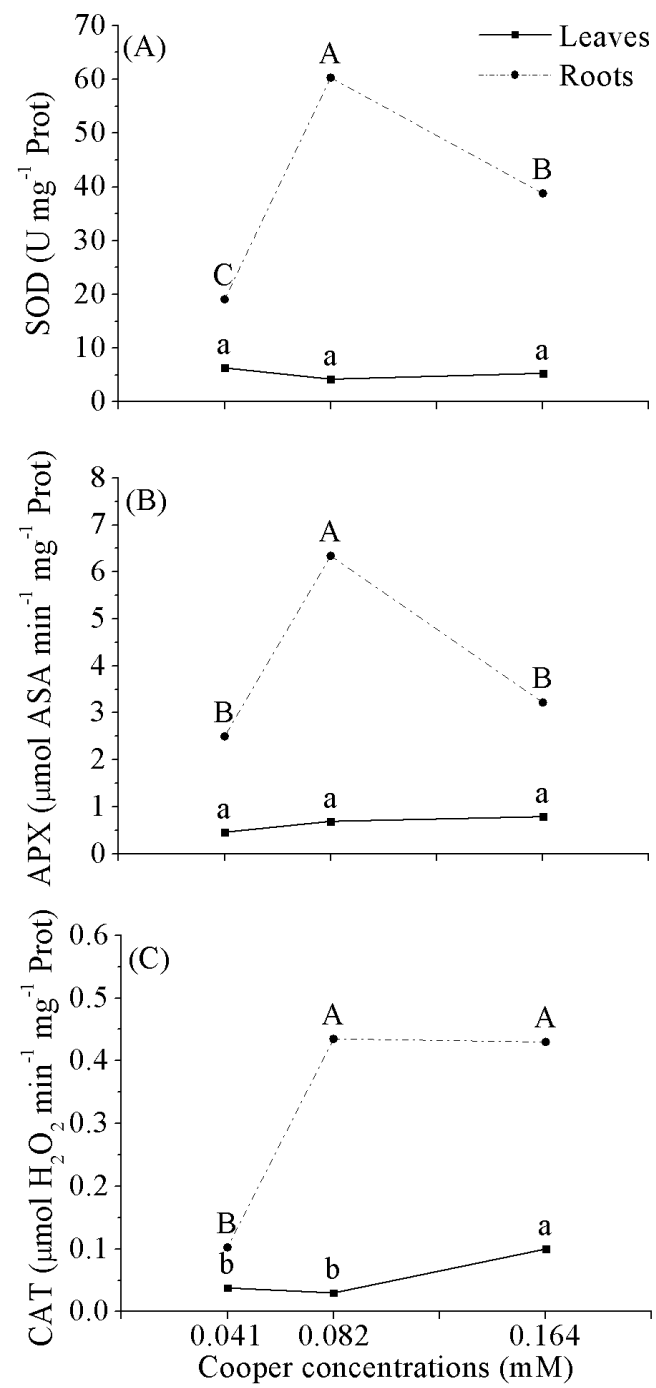
In the this study, activity of the antioxidant system was more pronounced in the root systems of the sweet potato plants than in the shoots (Figure 3 ), and this difference was mainly due to the low amounts of $\mathrm{Cu}$ found in the leaves when compared to that in the roots (Figure 2D). In the roots, SOD activity was 2.1 and 1.03 times greater at $0.082 \mathrm{mM}$ and $0.164 \mathrm{mM} \mathrm{Cu}$ concentrations, respectively, than at $0.041 \mathrm{mM} \mathrm{Cu}(\mathrm{p}=0.0006$; Figure $3 \mathrm{~A})$. APX activity at $0.082 \mathrm{mM} \mathrm{Cu}$ was 1.5 times greater than that at the lowest concentration observed, whereas plants grown at $0.164 \mathrm{mM} \mathrm{Cu}$ showed reduced APX activity, showing values equal to that observed in the control treatment $(\mathrm{p}=0.001$; Figure $3 \mathrm{~B})$. CAT activity in the roots grown at 0.082 and $0.164 \mathrm{mM}$ $\mathrm{Cu}$ was increased 3.2 times $(\mathrm{p}=0.01$; Figure $3 \mathrm{C})$.

A high amount of accumulated $\mathrm{Cu}$ in the roots induced oxidative stress, which may be proved by the increased activity of the antioxidant enzymes until $0.082 \mathrm{mM} \mathrm{Cu}$. However, at higher concentrations (0.164 mM), SOD and APX activities (Figure $3 \mathrm{~A}$ and $3 \mathrm{~B}$ ) were reduced and CAT activity (Figure 3C) remained constant. These results suggest that $0.082 \mathrm{mM}$ can be considered as a toxic $\mathrm{Cu}$ concentration because the roots induced combined activity of antioxidant enzymes. Plants that received the highest dose of $\mathrm{Cu}(0.164 \mathrm{mM})$ possibly developed exclusion and accumulation mechanisms (JANAS et al., 2010), as suggested by the high $\mathrm{Cu}$ content found in old leaves (Figure 2D). According to Kabata-Pendias and Pendias (2001), $\mathrm{Cu}$ at adequate concentrations has low mobility in plants, and most of this metal appears to remain in the roots and old leaf tissues until senescence. Only small amounts of this metal may move to young organs. However, the high supply of $\mathrm{Cu}$ may increase transport to senescent leaves and remove excess of this micronutrient. The decrease in SOD and APX activities also suggests that the increase in $\mathrm{Cu}$ availability $(0.164 \mathrm{mM})$ may have inhibited the expression of the enzymes involved in the antioxidant metabolism on a molecular level (MOURATO et al., 2009; POSMYK et al., 2009).
According to the results of this study, the roots were the main organ affected by the increased $\mathrm{Cu}$ availability in the solution. Root tissue, the first organ in contact with the metal, showed increased antioxidant enzyme activity. The roots were capable of carrying excess $\mathrm{Cu}$ to the shoots, probably because of increased $\mathrm{Cu}$ availability $(0.164 \mathrm{mM})$. In the old leaves, there was exclusion of excess $\mathrm{Cu}$. In the new leaves (Figure 3D), the nutrient caused a decrease in the chlorophyll index, changing the size of stomata and generating oxidative stress. The increase in CAT activity in the leaves occurred because of the formation of free $\mathrm{H}_{2} \mathrm{O}_{2}$ from the photorespiration process (Figure $3 \mathrm{C}$ ). This alternative pathway consumes the reduction power (NADPH) generated by the electron transport chain and not used in carbon metabolism (BUSSOTTI et al., 2011). On the basis of impairment of the biochemical phase of photosynthesis, it can be assumed that excess $\mathrm{Cu}$ in the leaves would cause NADPH accumulation because of a (1) decrease in the photosynthetic carbon assimilation cycle because high $\mathrm{Cu}$ concentrations caused a decrease in growth (Figure 1) and, possibly, inhibition of enzyme activity in the Calvin-Benson cycle, glyceraldehyde-3-phosphate dehydrogenase, and 3-phosphoglyceric acid kinase (BURZYNSKI; ZUREK, 2007); (2) reduction and/ or inhibition of Rubisco synthesis and activities of most enzymes related to nitrogen metabolism (such as nitrate reductase) because of the decrease in foliar N levels (CAMBROLLÉ et al., 2012); and (3) changes in the activity and structural maintenance of the photosynthetic apparatus as a result of a decrease in $\mathrm{Mg}$ and $\mathrm{Ca}$ content in the leaves (CAMBROLLÉ et al., 2013).

\section{Conclusion}

The sweet potato plants were able to tolerate $\mathrm{Cu}$ toxicity up to a specific concentration $(0.082$ $\mathrm{mM})$. Beyond this concentration, excess $\mathrm{Cu}$ was transported from the roots to the shoots, causing changes in morphological and anatomical 
characteristics and activating the antioxidant system because of the stress generated by excess $\mathrm{Cu}$.

\section{References}

ADAMSKI, J. M.; DANIELOSKI, R.; DEUNER, S.; BRAGA; E. J. B.; CASTRO, L. A. S.; PETERS, J. A. Responses to excess iron in sweet potato: impacts on growth, enzyme activities, mineral concentrations, and anatomy. Acta Physiologiae Plantarum, Poland, v. 34, n. 5, p. 1827-1836, 2012.

ADAMSKI, J. M.; PETERS, J. A.; DANIELOSKI, R.; BACARIN, M. A. Excess iron-induced changes in the photosynthetic characteristics of sweet potato. Journal of Plant Physiology, Leipzig, v. 168, n. 17, p. 2056-2062, 2011.

ANDRADE JÚNIOR, V. C.; VIANA, D. J. S.; PINTO, N. A. V. D.; RIBEIRO, K. G.; PEREIRA, R. C.; NEIVA, I. P.; AZEVEDO, A. M.; ANDRADE, P. C. R. Características produtivas e qualitativas de ramas e raízes de batata-doce. Horticultura Brasileira, Brasília, v. 30, n. 4, p. 584-589, 2012.

AZEVEDO, R. A.; ALAS, R. M.; SMITH, R. J.; LEA, P. J. Response from elevated carbon dioxide to air and ozone fumigation in leaves and roots of wild type and a catalase-deficient mutant of barley. Physiologia Plantarum, Copenhagem, v. 104, n. 2, p. 280-292, 1998.

BOOJAR, M. M. A.; GOODARZI, F. The copper tolerance strategies and the role of antioxidative enzymes in three plant species grown on copper mine. Chemosphere, Amsterdam, v. 67, n. 11, p. 2138-2147, 2007.

BRADFORD, M. M. A rapid and sensitive method for the quantitation of microgram quantities of protein utilizing the principle of protein-dye binding. Analytical Biochemistry, New York, v. 72, n. 1-2, p. 48-254, 1976.

BURKHEAD, J. L.; GOGOLIN REYNOLDS, K. A.; ABDEL-GHANY, S. E.; COHU, C. M.; PILON, M. Copper homeostasis. New Phytologist, Lancaster, v. 182, n. 4, p. 799-816, 2009.

BURZYNSKI, M.; ZUREK, A. Effects of copper and cadmium on photosynthesis in cucumber cotyledons. Photosynthetica, Praha, v. 45, n. 2, p. 239-244, 2007.

BUSSOTTI, F.; DESOTGIU, R.; CASCIO, C.; POLLASTRINI, M.; GRAVANO, E.; GEROSA, G.; MARZUOLI, R.; NALI, C.; LORENZINI, G.; SALVATORI, E.; MANES, F.; SCHAUBE, M.; STRASSER, R. J. Ozone stress in woody plants assessed with chlorophyll a fluorescence. A critical reassessment of existing data. Environmental and Experimental Botany, Paris, v. 73, n. 1, p. 19-30, 2011.

CAMBROLLÉ, J.; GARCÍA, J. L.; OCETE, R.; FIGUEROA, M. E.; CANTOS, M. Growth and photosynthetic responses to copper in wild grapevine. Chemosphere, Amsterdam, v. 93, n. 2, p. 294-301, 2013.

CAMBROLLÉ, J.; MANCILLA-LEYTÓN, J. M.; MUÑOZ-VALLÉS, S.; LUQUE, T.; FIGUEROA, M. E. Tolerance and accumulation of copper in the saltmarsh shrub Halimione portulacoides. Marine Pollution Bulletin, Coventry, v. 64, n. 4, p. 721-728, 2012.

CASSOL, D.; SILVA F. S. P.; FALQUETO, A. R.; BACARIN, M. A. An evaluation of non-destructive methods to estimate total chlorophyll content. Photosynthetica, Praha, v. 46, n. 4, p. 634-636, 2008.

CUTTER, E. G. Anatomia vegetal, parte I: células e tecidos. 2. ed. São Paulo: Roca, 1986. 304 p.

FIDALGO, F.; AZENHA, M.; SILVA, A. F.; SOUSA, A.; SANTIAGO, A.; FERRAZ, P.; TEIXEIRA, J. Copperinduced stress in Solanum nigrum L. and antioxidant defense system responses. Food and Energy Security, Harpenden, v. 2, n. 1, p. 70-80, 2013.

FOLONI, J. S. S.; CORTE, A. J.; CORTE, J. R. N.; ECHER, F. R.; TIRITAN, C. S. Adubação de cobertura na batata-doce com doses combinadas de nitrogênio e potássio. Semina: Ciências Agrárias, Londrina, v. 34, n. 1, p. 117-126, 2013.

GIANNOPOLITIS, C. N.; RIES, S. K. Superoxide dismutases. I. Occurrence in higher plants. Plant Physiology, Rockville, v. 59, n. 2, p. 309-314, 1997.

GLÓRIA, B. A.; GUERREIRO, S. M. C. Anatomia vegetal. 2. ed. Viçosa: UFV, 2006. 438 p.

HARICHOVÁ, J.; KARELOVÁ, E.; PANGALLO, D.; FERIANC, P. Structure analysis of bacterial community and their heavy-metal resistance determinants in the heavy-metal-contaminated soil sample. Biologia, Bratislava, v. 67, n. 6, p. 1038-1048, 2012.

HOAGLAND, D. R.; ARNON, D. The water-culture method for growing plants without soil. Berkeley: University of California College of Agriculture, Agricultural Experimental Station, 1938. 39 p.

JANAS, K. M.; ZIELINSKA-TOMASZEWSKA, J.; RYBACZEK, D.; MASZEWSKI, J.; POSMYK, M. M.; AMAROWICZ, R.; KOSINSKA, A. The impact of copper ions on growth, lipid peroxidation, and phenolic compound accumulation and localization in lentil (Lens culinaris Medic.) seedlings. Journal of Plant Physiology, Leipzig, v. 167, n. 4, p. 270-276, 2010. 
KABATA-PENDIAS, A.; PENDIAS, H. Trace elements in soils and plants. $3^{\text {th }}$ ed. Flórida: CRC Press, 2001. 315 p.

KRAUS, J. E.; ARDUIN, M. Manual básico de métodos em morfologia vegetal. Seropédica: EDUR, 1997. 198 p.

LARRÉ, C. F.; MARINI, P.; MORAES, C. L.; AMARNTE, L.; MORAES, D. M. Influência do 24-epibrassinolídeo na tolerância ao estresse salino em plântulas de arroz. Semina: Ciências Agrárias, Londrina, v. 35, n. 1 , p. $67-76,2014$.

LIU, J.; XIONG, Z. T.; LI, T.Y.; HUANG, H. Bioaccumulation and ecophysiological responses to copper stress in two populations of Rumex dentatus L. from $\mathrm{Cu}$ contaminated and non-contaminated sites. Environmental and Experimental Botany, Paris, v. 52, n. 1, p. 43-51, 2004.

LOW, J. W.; ARIMOND, M.; OSMAN, N.; CUNGUARA, B.; ZANO, F.; TSCHIRLEY, D. A food-based approach introducing orange-fleshed sweet potatoes increased vitamin A intake and serum retinol concentrations in young children in rural Mozambique. The Journal of Nutrition, Bethesda, v. 137, n. 5, p. 1320-1327, 2007.

MACHADO, A. de A.; CONCEIÇÃO, A. R. WinStat: sistema de análise estatística para Windows. Versão 2.0. Pelotas: UFPel/NIA, 2003.

MATEOS-NARANJO, E.; REDONDO-GÓMEZ, S.; CAMBROLLÉ, J.; FIGUEROA, M. E. Growth and photosynthetic responses to copper stress of an invasive cordgrass, Spartina densiflora. Marine Environmental Research, Ancona, v. 66, n. 4, p. 459-465, 2008.

MELONI, D. A.; OLIVA, M. A.; MARTINEZ, C. A.; CAMBRAIA, J. Photosynthesis and activity of superoxide dismutase, peroxidase and glutathione reductase in cotton under salt stress. Environmental and Experimental Botany, Paris, v. 49, n. 1, p. 69-76, 2003.

MITTLER, R. Oxidative stress, antioxidants and stress tolerance. Trends in Plant Science, Oxford, v. 7, n. 9, p. 405-410, 2002.

MOURATO, M. P.; MARTINS, L. L.; CAMPOSANDRADA, M. P. Physiological responses of Lupinus luteus to different copper concentrations. Biologia Plantarum, Praha, v. 53, n. 1, p. 105-111, 2009.

NAKANO, Y.; ASADA, K. Hydrogen peroxide is scavenged by ascorbate specific peroxidase in spinach chloroplasts. Plant Cell Physiology, Kyoto, v. 22, n. 5, p. $867-880,1981$.
PANOU-FILOTHEOU, H.; BOSABALIDIS, A. M.; KARATAGLIS, S. Effects of copper toxicity on leaves of oregano (Origanum vulgare subsp. hirtum). Annals of Botany, London, v. 88, n. 2, p. 207-214, 2001.

POSMYK, M. M.; KONTEK, R.; JANAS, K. M. Antioxidant enzymes activity and phenolic compounds content in red cabbage seedlings exposed to copper stress. Ecotoxicology and Environmental Safety, New York, v. 72, n. 2, p. 596-602, 2009.

RIBEIRO, M. N. O.; CARVALHO, S. P.; PEREIRA, F. J.; CASTRO, E. M. Anatomia foliar de mandioca em função do potencial para tolerância à diferentes condições ambientais. Revista Ciência Agronômica, Fortaleza, v. 43, n. 2, p. 354-361, 2012.

RUZIN, S. E. Plant microtechnique and microscopy. Oxford: Oxford University Press, 1999. 322 p.

SHI-SHENG, K. Effects of copper on the photosynthesis and oxidative metabolism of Amaranthus tricolor seedlings. Agricultural Sciences in China, v. 6, n. 10, p. 1182-1192, 2007.

SILVA, E. N.; FERREIRA-SILVA, S. L.; FONTENELE, A. V.; RIBEIRO, R. V.; VIÉGAS, R. A.; SILVEIRA, J. A. G. Photosynthetic changes and protective mechanisms against oxidative damage subjected to isolated and combined drought and heat stresses in Jatropha curcas plants. Journal of Plant Physiology, Leipzig, v. 167, n. 14, p. 1157-1164, 2010.

SILVA, L. M.; ALQUINI, Y.; CAVALLET, V. J. Interrelações entre a anatomia vegetal e a produção vegetal. Acta Botanica Brasilica, São Paulo, v. 19, n. 1, p. 183-194, 2005.

TEDESCO, M. J.; GIANELlO, C.; BISSANI, C. A.; BOHNEN, H. VOLKWEISS, S. J. Análise do solo, plantas e outros materiais, 2. ed. Porto Alegre: Departamento de Solos, UFRGS, 1995. 174 p.

THOUNAOJAM, T. C.; PANDA, P.; MAZUMDAR, P.; KUMAR, D.; SHARMA, G. D.; SAHOO, L.; PANDA, S. K. Excess copper induced oxidative stress and response of antioxidants in rice. Plant Physiology and Biochemistry, Bari, v. 53, n. 1, p. 33-39, 2012.

TICHÁ, I. Photosynthetic characteristics during ontogenesis of leaves: stomatal density and size. Photosynthetica, Praha, v. 16, n. 3, p. 375-471, 1982.

WINGLER, A.; QUICK, W. P.; BUNGARD, R. A.; BAILEY, K. J.; LEA. P. J.; LEEGOOD, R. C. The role of photorespiration during drought stress: an analysis utilizing barley mutants with reduced activities of photorespiratory enzymes. Plant, Cell and Environment, Maiden, v. 22, n. 4, p. 361-373, 1999. 
XIONG, Z. T.; LIU, C.; GENG, B. Phytotoxic effects of copper on nitrogen metabolism and plant growth in Brassica pekinensis Rupr. Ecotoxicology and Environmental Safety, New York, v. 64, n. 3, p. 273-280, 2006. 